\title{
Correction to: Activation and enhancement of caerulomycin A biosynthesis in marine-derived Actinoalloteichus sp. AHMU CJ021 by combinatorial genome mining strategies
}

Yunchang Xie', Jiawen Chen ${ }^{1}$, Bo Wang ${ }^{3,4}$, Tai Chen ${ }^{3,4}$, Junyu Chen ${ }^{1}$, Yuan Zhang ${ }^{2}$, Xiaoying Liu²* and Qi Chen ${ }^{2^{*}}$ (1)

\section{Correction to: Microb Cell Fact (2020) 19:159 https://doi.org/10.1186/s12934-020-01418 \\ -w}

Following publication of the original article [1], the authors have flagged that an incorrect version of Fig. $4 \mathrm{~b}$ has been published.

In the published version, the vertical dashed line is incorrectly positioned and the dummy variables are erroneously omitted from the y-axis.

To correct the version provided in the published article, please find (the corrected version of) Fig. $4 \mathrm{~b}$ in this correction.

The authors apologize for any inconvenience caused.

The original article can be found online at https://doi.org/10.1186/s1293 4-020-01418-w.

*Correspondence: liuxiaoying@ahmu.edu.cn; chenqi@ahmu.edu.cn

${ }^{2}$ School of Life Sciences, Anhui Medical University, Hefei 230032, China

Full list of author information is available at the end of the article

(c) The Author(s) 2020. This article is licensed under a Creative Commons Attribution 4.0 International License, which permits use, sharing, adaptation, distribution and reproduction in any medium or format, as long as you give appropriate credit to the original author(s) and the source, provide a link to the Creative Commons licence, and indicate if changes were made. The images or other third party material in this article are included in the article's Creative Commons licence, unless indicated otherwise in a credit line to the material. If material is not included in the article's Creative Commons licence and your intended use is not permitted by statutory regulation or exceeds the permitted use, you will need to obtain permission directly from the copyright holder. To view a copy of this licence, visit http://creativeco mmons.org/licenses/by/4.0/. The Creative Commons Public Domain Dedication waiver (http://creativecommons.org/publicdomain/ zero/1.0/) applies to the data made available in this article, unless otherwise stated in a credit line to the data. 


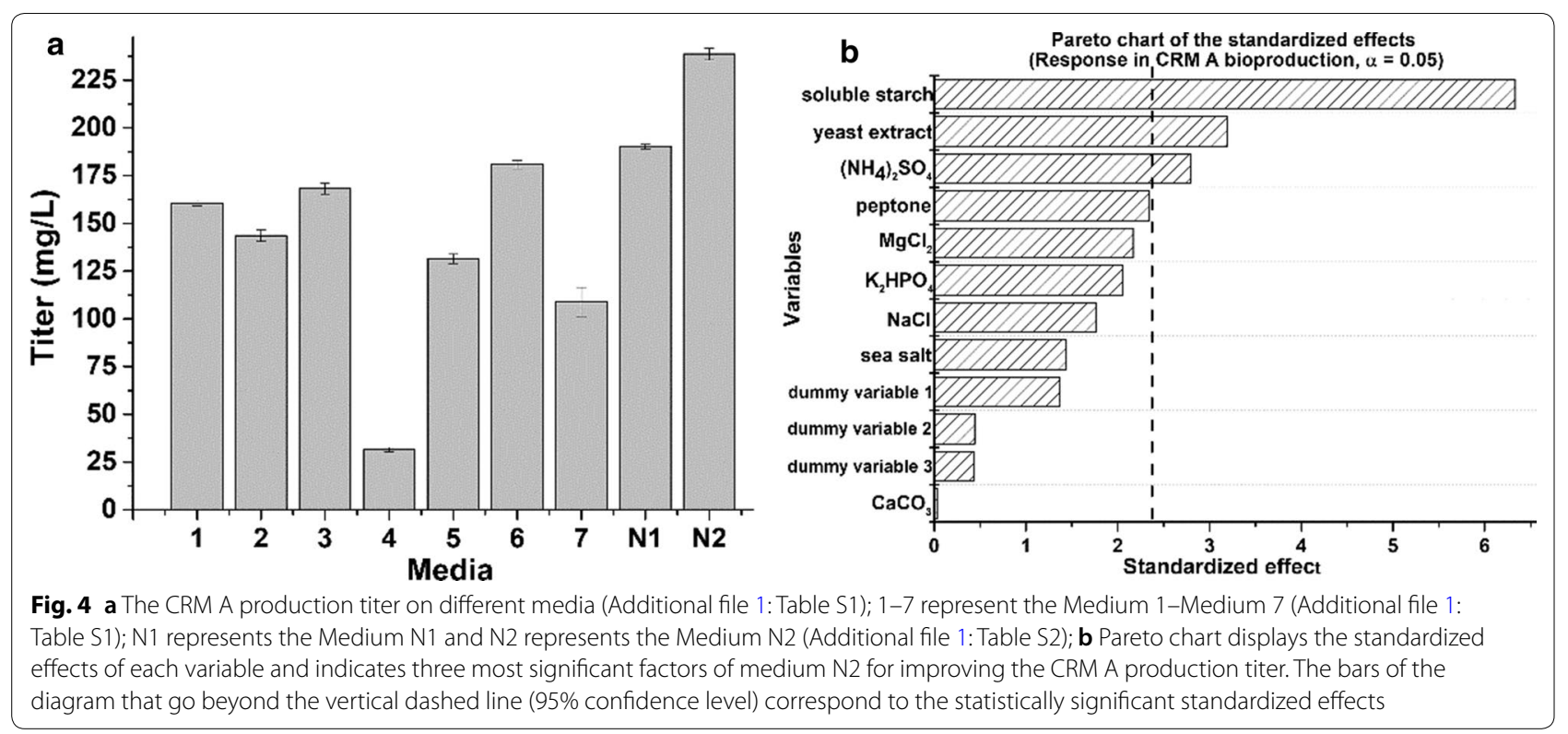

\section{Supplementary information}

Supplementary information accompanies this paper at https://doi. org/10.1186/s12934-020-01429-7.

Additional file 1: Table S1. Genome features of Actinoalloteichus sp. AHMU CJ021; Table S2. Number of genes associated with the general COG functional categories; Table S3. The biosynthetic gene clusters of secondary metabolites in Actinoalloteichus sp. AHMU CJ021 analyzed by antiSMASH 5.0; Table S4. Deduced functions of the open reading frames (ORFs) indicated in Fig. 2; Table S5. Fermentation media used for caerulomycin A (CRM A) production; Table S6. The mutants obtained from ribosome engineering experiments; Table S7. The CRM A production comparison of three camE-expressing mutants; Table S8. ${ }^{1} \mathrm{H}$ NMR and ${ }^{13} \mathrm{C}$ NMR spectral data of CRM A in DMSO-d6; Table S9. The comparison of selected mutants generated from UV mutagenesis; Table S10. CRM A production titer of optimal mutant XC-11GUR; Table S11. The dose of all factors in medium N2 by using Plackett-Burman Design; Table S12. Screening of significant variables for CRM A production in Medium N2 by using Plackett-Burman Design; Table S13. The effects of all factors of Medium N2 for CRM A production by using Plackett-Burman Design; Table S14. The dose of important factors in response surface analysis: Table S15. The design of experiments and response of CRM A production; Table S16. The primers used in identification of gentamycin-resistant mutant; Table S17. The primers used in gene expression analysis; Fig. S1. Phylogenetic tree of Actinoalloteichus sp. AHMU CJ021; Fig. S2. HR-ESI-MS spectrum of CRM A; Fig. S3. ${ }^{1} \mathrm{H}$ NMR spectrum of CRM A in DMSO-d6; Fig. S4. ${ }^{13} \mathrm{C}$ NMR spectrum of CRM A in DMSO-d6; Fig. S5. CRM A production comparison of different generations of mutants; Fig. S6. The quantitative HPLC standard curves.

\begin{abstract}
Author details
${ }^{1}$ Key Laboratory of Functional Small Organic Molecule Ministry of Education and Jiangxi's Key Laboratory of Green Chemistry, Key Laboratory of Protection and Utilization of Subtropic Plant Resources of Jiangxi Province, School of Life Sciences, Jiangxi Normal University, Nanchang 330022, China. ${ }^{2}$ School of Life Sciences, Anhui Medical University, Hefei 230032, China. ${ }^{3}$ Guangdong Provincial Key Laboratory of Genome Read and Write, Shenzhen Engineering Laboratory for Innovative Molecular Diagnostics, Guangdong Provincial Academician Workstation of BGI Synthetic Genomics, BGI-Shenzhen, Beishan Industrial Zone, Shenzhen 518083, China. ${ }^{4}$ China National GeneBank, BGI-Shenzhen, Jinsha Road, Shenzhen 518120, China.
\end{abstract}

Published online: 07 September 2020

\section{Reference}

1. Xie Y, Chen J, Wang B, Chen T, Chen J, Zhang Y, Liu X, Chen Q. Activation and enhancement of caerulomycin A biosynthesis in marine-derived Actinoalloteichus sp. AHMU CJ021 by combinatorial genome mining strategies. Microb Cell Fact. 2020;19(1):159. https://doi.org/10.1186/s1293 4-020-01418-w.

\section{Publisher's Note}

Springer Nature remains neutral with regard to jurisdictional claims in published maps and institutional affiliations.

Ready to submit your research? Choose BMC and benefit from:

- fast, convenient online submission

- thorough peer review by experienced researchers in your field

- rapid publication on acceptance

- support for research data, including large and complex data types

- gold Open Access which fosters wider collaboration and increased citations

- maximum visibility for your research: over $100 \mathrm{M}$ website views per year

At BMC, research is always in progress.

Learn more biomedcentral.com/submissions 